\title{
Spectinomycin in the treatment of gonorrhoea in males
}

\author{
R. R. WILLCOX \\ St. Mary's Hospital, London, W.2, and King Edward VII Hospital, Windsor
}

\section{The sulphate salt}

Spectinomycin (Trobicin; actinospectacin), an antibiotic prepared from Streptomyces spectabilis, was first used in the treatment of gonorrhoea a decade or so ago in the form of the sulphate salt. At this time cure rates of 87 to 95 per cent. were obtained using single intramuscular injections of $2 \mathrm{~g}$. in males (Willcox, 1962, 1963a; Laird and Taylor, 1962; Clarke, 1964; Beekman, 1965; Tiedemann, Hackney, and Price, 1965) while good results were also reported in the female, e.g. 23 of 25 cured by Sparling, Yobs, Billings, and Hackney (1965), with single injections of $3 \mathrm{~g}$.

The antibiotic was found to be ineffective in nongonococcal urethritis (Willcox, 1963b). As with streptomycin, the doses given in gonorrhoea were mildly active against syphilis, both in the clinical (Willcox, 1962) and in the experimental infection (Clark, Yobs, and Post, 1963, 1964). The latter workers considered its possible 'masking' qualities, although they were able to cure rabbit syphilis using arger doses.

\section{The dihydrochloride salt}

More recently a new salt, the dihydrochloride, has been prepared and a single $2 \mathrm{~g}$. dose has been reported to give highly satisfactory results in males with 90 to 100 per cent. of success as judged by the failure to recover gonococci after treatment, e.g. by Cornelius and Domescik (1970); Labowitz, Porter, and Holloway (1970); Platts (1970); Duncan, Holder, Roberts, and Knox (1972); Pedersen, Wiesner, Holmes, Johnson, and Turck (1972); Schroeter and Lucas (1972); Reyn, Schmidt, Trier, and Bentzon (1973); Stratigos, Marsellou-Kinti, Kassimatis, and Daikos (1973).

Similar or only slightly less success has been obtained by means of a single $4 \mathrm{~g}$. dose in females by

Received for publication November 1, 1973
Platts (1970), Labowitz and others (1970), Pedersen and others (1972), and Schroeter and Lucas (1972), and the same dose proved effective in twelve of fourteen cases of rectal gonorrhoea according to Holder, Roberts, Duncan, and Knox (1972).

High maximum, average, and minimum serum levels, well above the MIC of nearly all strains of the organism, are obtained with these doses during the first 6 hours after injection (Savage, 1973). The new preparation has also proved to be extremely well tolerated and the availability of a non-toxic injectable drug able to be given to persons suspected of being allergic to penicillin is in itself extremely useful now that streptomycin has become vitually useless (Willcox, 1973). Its use has indeed already been recommended in the United States for this purpose (Savage, 1973).

\section{Resistance patterns}

Of more importance is the question of gonococcal resistance. A correlation has been noted between penicillin-resistance and spectinomycin-resistance (Pedersen and others, 1972; Reyn and others, 1973) and in a patient failing to respond to spectinomycin the organism obtained after treatment showed a high degree of resistance to the antibiotic (Reyn and others, 1973). Laird and Taylor (1962) reported unsatisfactory results using low doses of the earlier sulphate preparation. They had two examples of increased spectinomycin resistance after treatment and indeed this may likewise be induced in vitro in the laboratory (Savage, 1973). However, this was not the experience of either Duncan and others (1972) or Pedersen and others (1972) after the use of satisfactory doses of the newer salt.

There are also geographical patterns of resistance of the gonococcus to antibiotics. Reyn and others (1973) found that gonococcal strains from Odense were more sensitive to spectinomycin than those from the whole of Denmark which included a large number from the capital, Copenhagen. Certainly, with 
ampicillin cure rates after a single dose of $2 \mathrm{~g}$. plus probenecid were appreciably better when administered in Wales than in London and its environs (Cobbold, Rees, Parker, Woodcock, John, Latto, Redmond, and Willcox, 1973).

Now that the dihydrochloride salt of spectinomycin is available, and because resistance patterns also may change with time, it was considered worthwhile to reassess the effectiveness of the antibiotic in acute gonorrhoea in males in London and to compare the results with those obtained in patients examined and treated under like conditions a decade or so previously.

\section{Patients}

100 male patients with acute uncomplicated urethral gonorrhoea were each treated with a single intramuscular injection of $2 \mathrm{~g}$. spectinomycin dihydrochloride pentahydrate.

36 of these patients were born in the United Kingdom and 64 were immigrants. Of the latter, thirty were Negroes (27 from the West Indies and three from West Africa) and 34 were other immigrants from 21 different countries (five from Eire, three each from Greece and Spain, two each from Australia, Austria, India, Iraq, and Turkey, and one each from Ceylon, Czechoslovakia, Egypt, France, Italy, Iran, Kenya, Lebanon, Malaysia, Morocco, Mauritius, Pakistan, and the U.S.A.). Nineteen were married, five were separated, and 76 were single. Their average age was 27.9 years (range 17 to 55 ).

The urethral discharge was present before treatment for 1 to 3 days in 64 cases, 4 to 7 days in 28 cases, 8 to 14 days in five, and 15 to 21 days in two; in one case the duration was not known. 85 patients had experienced some dysuria and fifteen had not.

Only 45 of the patients had had no previous venereal infection, the remaining having experienced no less than 209 previous incidents, including 129 of gonorrhoea, 51 of non-gonococcal urethritis, four of syphilis, eighteen of other suspected sexually-transmitted conditions, and seven of anxiety concerning venereal disease.

No less than 132 of these incidents (including 91 of gonorrhoea and 29 of non-gonococcal urethritis) had affected the thirty Negroes, only six of whom had never before attended a venereal disease clinic, and who thus between them averaged 4.4 previous incidents each compared with $1 \cdot 1$ for the remainder. One West Indian patient accounted for 31 previous incidents, including 29 of gonorrhoea, and this man and two others for no less than 52 previous incidents.

The disease had apparently been caught from a female stranger in 43 instances, from a female friend in 48 , from the wife in two, and from a man in six (being a friend in four and a stranger in two cases); one man denied sexual intercourse. The apparent incubation period was 1 to 3 days in 49 cases, 4 to 7 days in 29 cases, 8 to 14 days in fifteen, 15 to 21 days in two, and was not known in five.

\section{Case management}

Diagnosis was made routinely by Gram-stained urethral smear in all cases before treatment when Wassermann and VDRL serum tests for syphilis were also performed. Both of these proved negative in all patients apart from one West Indian in whom a weakly positive VDRL was obtained with a negative Wassermann reaction.

All patients received a single intramuscular injection of spectinomycin dihydrochloride pentahydrate, the $2 \mathrm{~g}$. powder being dissolved in the $3.2 \mathrm{ml}$. bacteriostatic water containing $9 \mathrm{mg} . / \mathrm{ml}$. benzyl alcohol provided. After treatment the patients were instructed to return after 3 to 4 days, when the urethra was examined for discharge and the urine for haze and threads. Urethral smears and cultures for the gonococcus on Thayer-Martin medium were also made after treatment in 68 per cent. of those followed and in no case was a positive culture obtained with a negative smear. Re-treatment because of pus cells in the urethra was discouraged at the first follow-up visit.

Subsequently the patients were instructed to attend again approximately $1,3,7$, and 12 weeks later, when the urethra was again examined for discharge (a smear and culture being made if discharge was present) and the urine for haze and threads; a final serum test for syphilis was made at the last visit.

\section{Follow-up and results}

By no means all patients attended at the times requested but sufficient time has elpased for all to have been able to attend for at least 3 months. The follow-up and results so far obtained are shown in Table I (overleaf).

Thus, of 100 patients treated, 83 were followed. The status of 55 was satisfactory at the last visit, twelve were treated for a non-gonococcal infection and, judging by the presence or absence of a history of further sexual exposure, there were nine reinfections and seven ( 8.4 per cent.) suspected treatment failures.

There are no satisfactory criteria to distinguish relapse from re-infection. Curtis and Wilkinson (1958), basing their findings on the sensitivity patterns of the gonococcus to penicillin before and after treatment, considered that, if all recurrences within 1 week regardless of history were assumed to be failures and those after this time re-infections, such a classification would probably not be wide of the mark. The present author has regarded 2 weeks as more realistic. If 2 weeks is taken in the present series, the failure rate is the same ( 8.4 per cent.).

One of the treatment failures was re-treated with 2.4 m.u. aqueous procaine penicillin with probenecid and this also failed; the condition finally responded to an injection of $2 \mathrm{~g}$. kanamycin. 
TABLE I Follow-up and results

\begin{tabular}{|c|c|c|c|c|c|}
\hline Duration of follow-up & No. followed & Satisfactory & $\begin{array}{l}\text { Non-gonococcal } \\
\text { infection }\end{array}$ & Re-infection & $\begin{array}{l}\text { Failure based } \\
\text { on history }\end{array}$ \\
\hline 0 & 100 & - & - & - & - \\
\hline 1-7 days & 83 & 16 & - & - & 6 \\
\hline 8-14 days & 61 & 10 & $2^{\mathrm{a}}$ & 1 & - \\
\hline $15-21$ days & 48 & 8 & 2 & - & 1 \\
\hline $22-28$ days & 37 & 3 & 2 & 2 & - \\
\hline $1-2 \mathrm{mths}$ & 30 & 9 & 2 & 3 & - \\
\hline $2-3 \mathrm{mths}$ & 16 & 3 & 3 & 2 & - \\
\hline More than $3 \mathrm{mths}$ & 8 & 6 & 1 & 1 & - \\
\hline Total & 83 & 55 & 12 & 9 & $\begin{array}{l}7 \\
(8.4 \text { per cent. })\end{array}$ \\
\hline
\end{tabular}

${ }^{a}$ One with a rectal infection

RESULTS ACCORDING TO ETHNIC GROUPS (Table II) More than one-half of the failures based on history arose in the Negro group which, as has already been indicated, had the highest incidence of previous venereal disease; the risk of immediate re-infection may therefore be expected to be higher in spite of the denial of further sexual exposure. In the seventy other patients the failure rate amongst those followed was only $5 \cdot 1$ per cent. ( 3 of 59 followed).

\section{COMPARISON WITH EARLIER RESULTS USING SULPHATE} SALT

In an attempt to ascertain whether the gonococcus had become less sensitive to spectinomycin in the past 10 years a comparison has been made in Table III with the earlier findings using the sulphate salt.

Whether based on history, or on all recurrences within 2 weeks regardless of history, the failure rate in London in the present series in which spectinomycin dihydrochloride was used did not differ significantly from that of a decade ago using the sulphate salt.

\section{SIDE-EFFECTS}

The drug was extremely well tolerated and no patient complained of any local or systemic sideeffect.

\section{Summary and conclusions}

(1) 100 male patients with acute uncomplicated gonorrhoea in London were treated with single injections of $2 \mathrm{~g}$. spectinomycin. Whether based on a denial of further sexual intercourse or on all recurrences within 2 weeks regardless of such history, there were seven failures $(8.4$ per cent. of the 83 patients followed).

TABLE II Results according to ethnic groups

\begin{tabular}{|c|c|c|c|c|c|c|c|}
\hline \multirow[t]{2}{*}{ Group } & \multirow[t]{2}{*}{ No. treated } & \multirow[t]{2}{*}{ No. followed } & \multirow[t]{2}{*}{ Satisfactory } & \multirow[t]{2}{*}{$\begin{array}{l}\text { Non-gonococcal } \\
\text { infection }\end{array}$} & \multirow[t]{2}{*}{ Re-infection } & \multicolumn{2}{|c|}{$\begin{array}{l}\text { Failure based on } \\
\text { history }\end{array}$} \\
\hline & & & & & & No. & Per cent. \\
\hline $\begin{array}{l}\text { Negroes } \\
\text { Other immigrants } \\
\text { U.K.-born }\end{array}$ & $\begin{array}{l}30 \\
34 \\
36\end{array}$ & $\begin{array}{l}24 \\
32 \\
27\end{array}$ & $\begin{array}{l}16 \\
20 \\
19\end{array}$ & $\begin{array}{l}2 \\
5 \\
5\end{array}$ & $\begin{array}{l}2 \\
5 \\
2\end{array}$ & $\begin{array}{l}4 \\
2 \\
1\end{array}$ & $\begin{array}{r}16 \cdot 7 \\
6 \cdot 3 \\
3 \cdot 7\end{array}$ \\
\hline Total & 100 & 83 & 55 & 12 & 9 & 7 & $8 \cdot 4$ \\
\hline
\end{tabular}

TABLE III Present results compared with earlier findings using the sulphate salt

\begin{tabular}{|c|c|c|c|c|c|c|}
\hline \multirow{2}{*}{ Series } & \multirow{2}{*}{ No. treated } & \multirow{2}{*}{ No. followed } & \multicolumn{2}{|c|}{ All recurrences within 2 weeks } & \multicolumn{2}{|c|}{ Failure based on history } \\
\hline & & & No. & Per cent. & No. & Per cent. \\
\hline Present study (1973) & 100 & 83 & 7 & $8 \cdot 4$ & 7 & $8 \cdot 4$ \\
\hline $\begin{array}{l}\text { Willcox }(1962) \\
\text { Willcox }(1963)^{a}\end{array}$ & $\begin{array}{l}101 \\
151\end{array}$ & $\begin{array}{r}89 \\
134\end{array}$ & $\begin{array}{r}6 \\
11\end{array}$ & $\begin{array}{l}6 \cdot 7 \\
8 \cdot 2\end{array}$ & $\begin{array}{r}7 \\
13\end{array}$ & $\begin{array}{l}7.9 \\
9 \cdot 7\end{array}$ \\
\hline
\end{tabular}

aIncluded the 1962 patients 
(2) The failure rate among the Negro patients was 16.7 per cent. ( 4 of 24 followed); among those born in the United Kingdom it was only 3.7 per cent. ( 3 of 59 followed).

(3) The results are similar to those obtained with the sulphate salt under comparable conditions a decade before.

\section{References}

Beekman, E. M. (1965) Dermatologica (Basel), 131, 262 Clark, J. W., Yobs, A. R., and Post, W. E. (1963) Brit. f. vener. Dis., 39, 184

$\longrightarrow,-$, (1964) Ibid., 40, 53

Clarke, G. H. V. (1964) Ibid., 40, 122

Cobbold, R. J. C., Rees, G. D., Parker, R. B., WoodCOCK, K. R., John, J., Latto, D., ReDmond, A., and WILlCox, R. R. (1973) Ibid., 49, 268

Cornelius, L. E., and Domescik, G. (1970) Ibid., 46, 212

CURTIS, F. R., and WILkINSON, A. F. (1958) Ibid., 34, 70

Duncan, W. C., Holder, W. R., Roberts, D. P., and Knox, J. M. (1972) Antimicrob. Agents Chemother., 1,210

Holder, W. R., Roberts, D. P., Duncan, W. C., and Knox, J. M. (1972) Brit. F. vener. Dis., 48, 274

Labowitz, R., Porter, W. L., and Holloway, W. J. (1970) Delaware med. f., 42, 353

LAIRD, S. M., and TAYloR, G. (1962) Brit. F. vener. Dis., 38, 60

Pedersen, A. H. B., Wiesner, P. J., Holmes, K. K., Johnson, C. J., and TurCK, M. (1972) f. Amer. med. Ass., 220, 205

Platts, W. M. (1970) Med. F. Aust., 2, 500

Reyn, A., Schmidt, H., Trier, M., and Bentzon, M. W. (1973) Brit. F. vener. Dis., 49, 54
Savage, G. M. (1973) Paper presented at 50th Anniversary meeting of La Ligue Nationale Belge Anti-vénérienne, Brussels, May, 1973

SCHROETER, A. L., and LuCAS, J. B. (1972) Obstet. and Gynec., 39, 274

Sparling, P. F., Yobs, A. R., Billings, T. E., and HACKNEY, J. F. (1965) in 'Antimicrobial Agents and Chemotherapy', ed. G. L. Hobby, p. 689. American Society for Microbiology

Stratigos, J. D., Marsellou-Kinti, O., Kassimatis, V., and DaIkos, G. K. (1973) Brit. F. vener. Dis., 49, 60

Tiedemann, J. H., Hackney, J. F., and Price, E. V. (1965) f. Amer. med. Ass., 191, 89

Willcox, R. R. (1962) Brit. F. vener. Dis., 38, 150

- (1963a) Acta derm.-venereol. (Stockh.), 43, 399

(1963b) Brit. F. vener. Dis., 39, 21

- (1973) In 'Current Antibiotic Therapy', ed. A. M. Geddes and J. D. Williams, pp. 195-210. Churchill, Livingstone, London

La spectinomycine dans le traitement de la gonococcie masculine

\section{SOMMAIRE}

(1) A Londres, 100 hommes atteints de gonococcie aigüe non compliquée furent traités par une injection unique de $2 \mathrm{~g}$ de spectinomycine. En tenant compte ou non de la dénégation de tout rapport sexuel ultérieur, le total des rechutes en deux semaines fut de $7(8,4$ pour cent) sur les 83 malades suivis.

(2) Le taux d'echec chez les malades noirs fut de 16,7 pour cent ( 4 des 24 suivis); parmi ceux nés au Royaume Uni, il ne fut que de 3,7 pour cent ( 3 des 59 suivis).

(3) Ces résultats sont semblables à ceux obtenus une décennie auparavant avec le sulfate dans des conditions comparables. 